\title{
Endovascular Treatment of Intracranial Aneurysms in Elderly Patients
}

\author{
Sung-Kyun Hwang $\cdot$ Sung-Hak Kim \\ Department of Neurosurgery, College of Medicine, Ewha Womans University$$
=\text { 국 문 초록 }=
$$ \\ 고령의 뇌동맥류 환자에 대한 혈관내수술 치료 \\ 이화여자대학교 의학전문대학원 신경외과학교실 \\ 황 승 균·김 성 학
}

목 적 : 고령에서의 뇌동맥류 출혈로 인한 외지주막하 출혈이 증가추세에 있다. 나이가 증가함에 따른 혈관수술 위험성도 높아진다. 이 연구의 목적은 혈관내 코일색전술을로 치료한 고령의 뇌지주막하출혈환자 에게서 시술적 및 임상적 결과를 평가함에 있다.

방 법 : 2004년 9월부터 2008년 8월까지 본원에서 혈관내 코일색전술을로 치료한 65세 이상의 고령의 뇌지주막하출혈환자 45 명을 연구의 대상으로 삼았다. 이 연구의 모든 환자에게서 혈관내 코일색전술을 일 차적인 치료를 하였다. 임상적 변수, 시술과정에서의 기술적 문제에 대한 정보, 시술합병증, 그리고, 임상적 결과를 평가하였다,

결 과 : 입원시의 임상적 등급이 Hunt \& Hess I-II인 경우가 $58 \%, \mathrm{H} \& \mathrm{H}$ III인 경우가 $29 \%$, 그리고, $\mathrm{H} \& \mathrm{H}$ III인 경우가 $15 \%$ 이였다. 후순환동맥류의 빈도는 전체의 $8.8 \%$ 이였다. 코일색전술은 전체의 $95 \%$ 에 서 성공적으로 시술되었다(2명의 환자의 경우는 시술을 시도 하였으나 성공하지 못 하였다). 치료한 뇌동맥 류의 패색정도는 $67 \%$ 에서 완전히 폐색되었고, $16 \%$ 에서는 뇌동맥류 기시부 부분이 잔존하였고, $13 \%$ 에서 는 뇌동맥류의 일부 잔류부분에 있었고, 4 명의 환자는 치료가 시도되지 못 하였다. 시술합병증의 비율은 $8 \%$ 이였고, 6 개월 후 결과는 $65 \%$ 에서 성공적이었고, $27 \%$ 에서는 심한 장애가 있었고, $9 \%$ 에서는 부정적인 결과를 보였다.

결 론 : 65 세 이상의 고령의 뇌지주막하출혈환자에서의 혈관내 코일색전술 치료는 재출혈 방지에 효과 적 이었고, 일부 선택된 환자에게서는 개두술보다 작은 유병률 및 치사율로 대체치료법으로 대변된다. 본 연구의 결과에서 보듯이 혈관내 수술치료법이 대부분의 경우 성공적인 결과를 보이기 때문에 고령의 환 자에게서는 일차적인 치료법이 될 수 있을 것으로 사료된다.

중심 단어 : 혈관내수술 치료·뇌지주막하출혈· 파열 동맥류·고령 환자.

Address for correspondence: Sung-Kyun Hwang, MD

Department of Neurosurgery, College of Medicine, Ewha Womans University, 911-1 Yangcheon-gu, Seoul $158-710$, Korea

Tel : (02) 2650-2872·전송 : (02) 2650-0948·E-mail : nshsg@ewha.ac.kr 


\section{Introduction}

The definition of an elderly person is debateable ; however, age is a recognised negative prognostic factor for outcome after subarachnoid haemorrhage, and the age cut-off of 65 years is accepted to define a high risk population. As a result of the aging population in the west and the increased incidence of SAH in elderly patients, ruptured intracranial aneurysm is an increas-ingly fre-

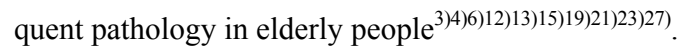

Endovascular treatment of intracranial aneurysms has made remarkable progress over the last 10 years and become widely used ${ }^{5(8) 16) 24) 28)}$. Moreover, selective embolization with detachable coils has been accepted as an alternative to surgical clipping, with lower morbidity and mortality rates in select cases. Because embolization is less invasive than surgery, it allows us to treat more patients, including elderly individuals, in whom surgical clipping is considered risky. Endovascular treatment is now recognized as an alternative to surgical treatment, especially for patients in poor general health and for lesions of the posterior circulation ${ }^{12)(9) 17) 2025)}$. Nevertheless, no study assessing the results of endovascular treatment in relation to age have been undertaken, and the effectiveness of embolization in elderly patients is yet to be determined.

However, little information is available about its feasibility and effectiveness in elderly patients. We assessed clinical outcomes and results with ruptured intracranial aneurysms treated with selective embolization. And, we compared endovascular therapy results with previous published data.

The goal of this article is to access the outcome in this precise population of patients that underwent endovascular treatment after aneurysm rupture.

\section{Patients and Methods}

The selection criteria for this study were : 1) spontaneous SAH between September 2004 and August 2008, 2) age 65 years or older at time of $\mathrm{SAH}, 3$ ) aneurysm rupture as the cause of $\mathrm{SAH}, 4)$ endovascular aneurysm treatment chosen as the first line of treatment, and 5) that aneurysm repair treatment was given at the acute stage after hemorrhage (within 3 weeks of aneurysm rupture) 6) Patients with fusiform, traumatic, or mycotic aneurysm were excluded from the study. All patients underwent conventional angiography of both carotid arteries and vertebral arteries. Table 2 . shows the location of the aneurysms, $92 \%$ of which were in the anterior circulation and $8 \%$ of which were in the posterior circulation. Multiple aneurysms were seen in 8 patients $(17.6 \%)$, but only those responsible for the SA$\mathrm{H}$ were treated. The clinical state of all patients treated by embolization was assessed 6 months after treatment with the use of the Glasgow Outcome Scale (GOS). We define the good recovery (GOS score 5) and moderate disability (GOS score 4) as a 'favorable', severe disability (GOS score 3 ) and persistent vegetative state (GOS score 2) as a 'severe disability' and death (GOS score 1) as a 'poor outcome'.

\section{Endovascular Embolization Procedure}

Coiling of aneurysms was performed on a biplane angiographic unit (Integris BN 3,000 ; Phillips Medical Systems, Best, the Netherlands). Embolization was performed after induction of general anesthesia and systemic heparinization (3,000 IU bolus, followed by continuous intraarterial infusion of heparin at 1,000 IU/hour) and maintenance of an activated coagulation time more than twice the control value. Aneurysms were embolized using size 10 soft GDCs (Guglielmi detachable coils, Boston Scientific, Boston, USA) 2 or $3 \mathrm{~mm}$ in diameter. After road mapping was performed using clear magnified images, a microcatheter(Excelsior SL-10 ; Boston Scientific, Boston, USA or Prowler 14 ; Cordis, Miami, USA) was carefully inserted into the aneurysm over the guidewire, and coils were then introduced. The aim of coiling was obtain an attenuated packing of the aneurysm, until not a single coil could be placed. In the occurrence of aneurysm perforation during coiling, heparin was reversed instantaneously and coiling was continued until the bleeding stopped. In the occurrence of thromboembolic complications. usually a selective bolus injection of $100,000-250,000 \mathrm{U}$ of urokinase was administered in the involved vessel, followed from 2002 onward by intrave- 
nous infusion of a glycoprotein IIb/IIIa antagonist (tirofiban ; Aggrastat, Merck \& Co., USA), titrated to 2 to 3 times normal values of activated thromboplastin time. After embolization, anticoagulation therapy was stopped.

\section{Results}

Between September 2004 and August 2008, 139 patients with 147 intracranial aneurysms were treated in our hospital by means of an endovascular approach. Among them, 45 patients (32\%) with a ruptured aneurysm were aged 65 years or older. They included 38

Table 1. Patient characteristics

\begin{tabular}{lr}
\hline Patient characteristics & $\mathrm{N}(\%)$ \\
\hline Sex & $38(84)$ \\
Female & $7(16)$ \\
Male & \\
Age (years) & $12(26)$ \\
$65-9$ & $22(48)$ \\
$70-4$ & $11(24)$ \\
$>75$ & \\
Day of procedure & $29(64)$ \\
0 & $9(20)$ \\
1 & $7(15)$ \\
$>1$ & \\
Hunt \& Hess grade on admission & $26(58)$ \\
H\&H I-II & $13(29)$ \\
H\&H III & $6(13)$ \\
H\&H IV-V & \\
Fisher grade & $13(29)$ \\
$1-2$ & $32(71)$ \\
$3-4$ &
\end{tabular}

Table 2. Distribution of ruptured aneurysms

\begin{tabular}{lc}
\hline Aneurysm location & $\mathrm{N}(\%)$ \\
\hline Al-ACom-A2 & $13(29)$ \\
ICA-PComA & $19(42)$ \\
MCA & $9(20)$ \\
BA trunk & $3(4)$ \\
SCA & $1(2)$ \\
VA & $1(2)$ \\
Total & 45 \\
\hline ACom : Anterior communicating artery, ICA : Internal \\
carotid artery, PCom : Posterior communicating ar- \\
tery, MCA : Middle cerebral artery, BA : Basilar artery, \\
SCA : superior cerebellar artery, VA : Vertebral artery
\end{tabular}

women $(84 \%)$ and 7 men (16\%) with a mean age of 71 years (range, 65-82 years) (Table 1). All patients presented with subarachnoid hemorrhage $(\mathrm{SAH})$ and were classified according to the Hunt and Hess $(\mathrm{H}-\mathrm{H})$ scale (Table 4). Twenty-six patients $(58 \%)$ were assigned grade I or II ; $13(29 \%)$, grade III ; 6, and grade IV$\mathrm{V}(13 \%)$. In 45 patients, 38 patients for embolization was performed within 24 hours after initial bleeding. The

Table 3. Degree of occlusion, procedural complications and outcome $(n=45)$

\begin{tabular}{lc}
\hline & $\mathrm{N}(\%)$ \\
\hline Degree of occlusion & $30(67)$ \\
Complete & $7(16)$ \\
Neck remnant & $6(13)$ \\
Residual filling & $2(4)$ \\
Not treated & 45 \\
Total & \\
Complications & $1(2)$ \\
Parent artery occlusion & $1(2)$ \\
Coil migration & $2(4)$ \\
Coil herniation & $4(8)$ \\
Total & \\
Outcome at 6 months & $29(65)$ \\
Favorable & $12(27)$ \\
Severe disability & $4(9)$ \\
Poor &
\end{tabular}

Table 4. Hunt and Hess classification of subarachnoid hemorrhage

\begin{tabular}{cc}
\hline Grade & Description \\
\hline 1 & $\begin{array}{c}\text { Asymptomatic, or mild headache and slight } \\
\text { nuchal rigidity }\end{array}$ \\
2 & $\begin{array}{c}\text { Cranial palsy (e.g. lii, vi). Moderate to severe } \\
\text { headache, nuchal rigidity }\end{array}$ \\
3 & Mild focal deficit, lethargy, or confusion \\
4 & Stupor, moderate to severe hemiparesis, early \\
decerebrate rigidity & Deep coma, decerebrate rigidity, moribund ap- \\
& Pearance
\end{tabular}

Table 5. Grading system of fisher

\begin{tabular}{cl}
\hline Group & Blood on ct \\
\hline 1 & No subarachnoid blood detected \\
2 & Diffuse or vertical layers ${ }^{\ddagger}<1 \mathrm{~mm}$ thick \\
3 & Localized clot and/or vertical layer ${ }^{\ddagger} \geq 1 \mathrm{~mm}$ \\
4 & Intracerebral or intraventricular clot with dif- $^{\text {fuse or no SAH }}$ \\
\hline
\end{tabular}


others were treated in our department 3 weeks after the initial SAH. Successful embolization means complete or near complete (small residual neck remnant) obliter-

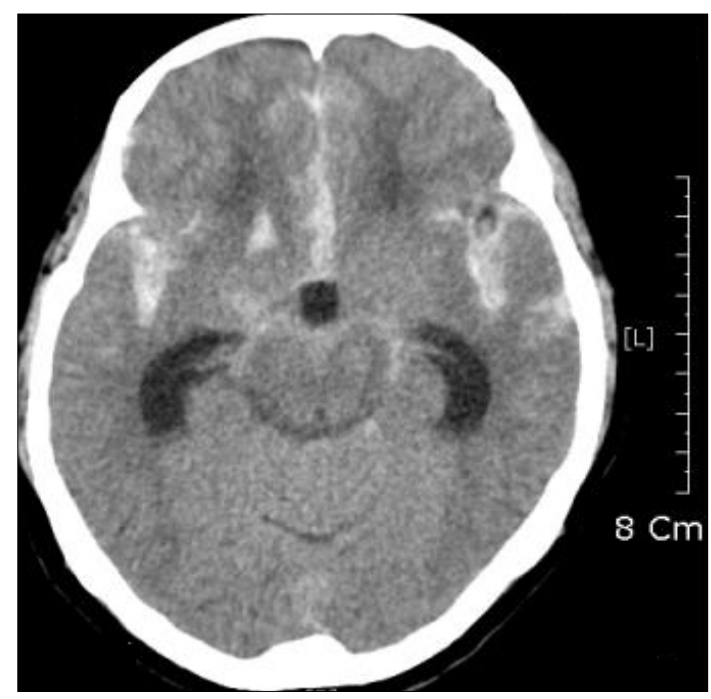

Fig. 1. 72-aged female patient admitted with loss of consciousness, computed tomography (CT) shows diffuse subarachnoid hemorrhage in basal cistern. ation of aneurysmal sac as much as to prevent the rebleeding without a technical and clinical complications. Endovascular treatment resulted in 30 complete occlusions $(67 \%)$ (Fig. 1, 2, 3), 7 neck remnants $(16 \%), 6$ residual filling and attempted cases $(4 \%)$. Procedural com-

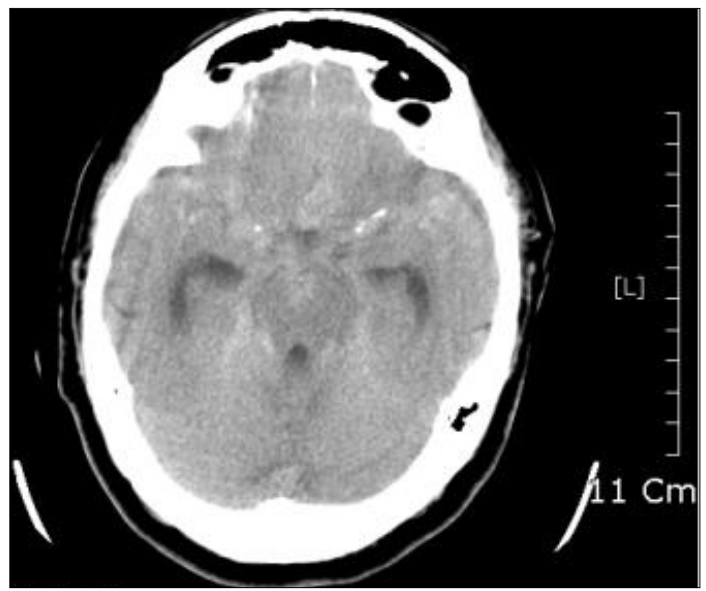

Fig. 4. 67-aged female patient admitted with loss of consciousness, CT shows the hydrocephalus with diffuse subarachnoid hemorrhage in basal cistern.
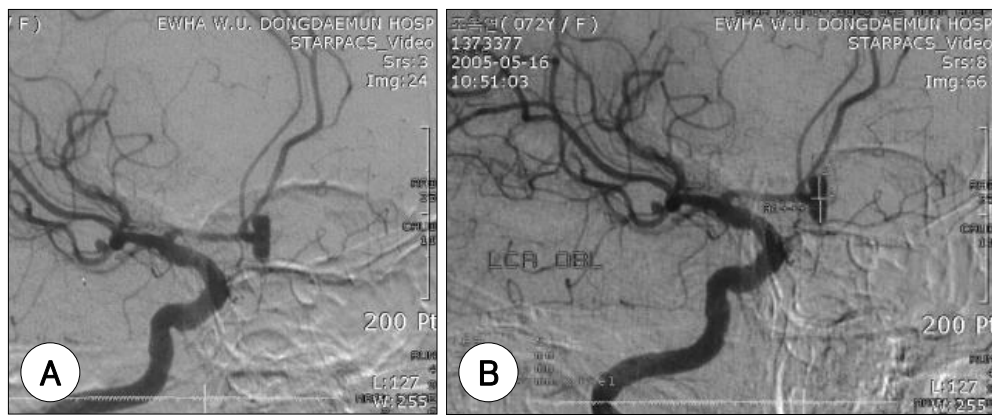

Fig. 2. A, B : Cerebral angiogrophy shows soccular aneurysm in anterior communicating artery.
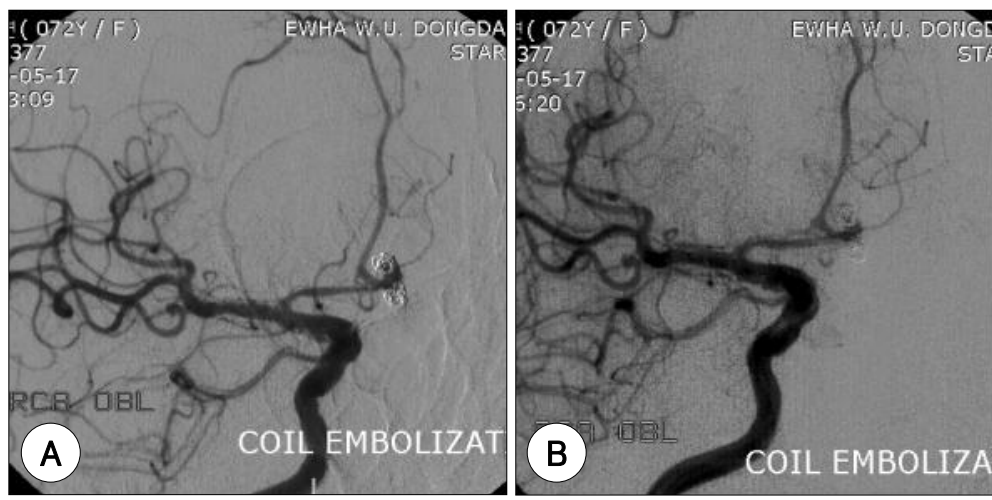

Fig. 3. A, B : Post-embolization angiography shows successful obliteration of aneurysm. 

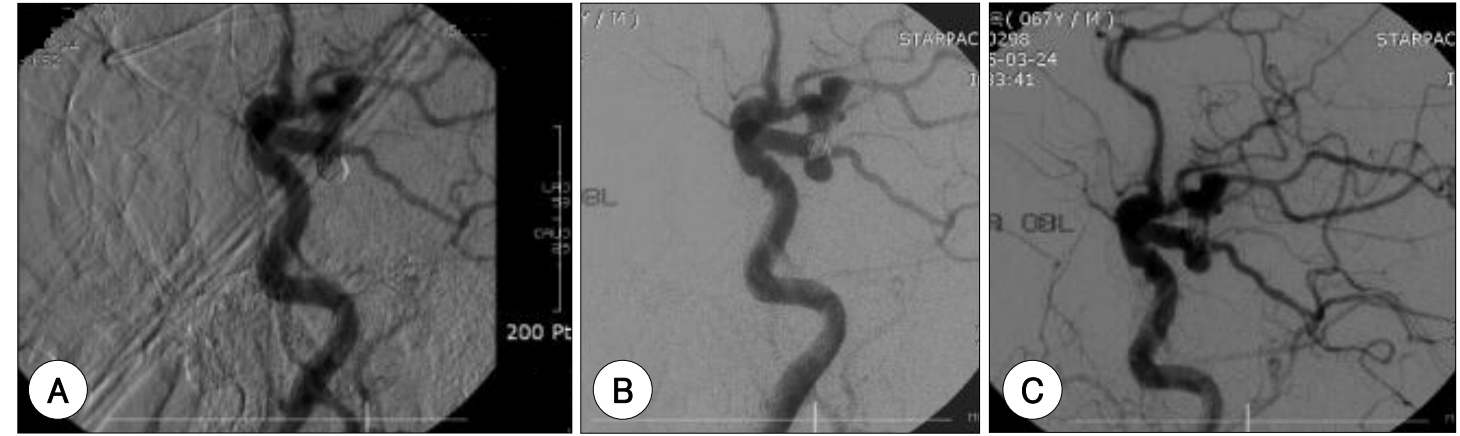

Fig. 5. A : Cerebral angiography shows saccular aneurysm in posterior communicating artery, and obliteration of aneurysm. B, C : Angiography shows migration of coil mass in internal carotid artery.
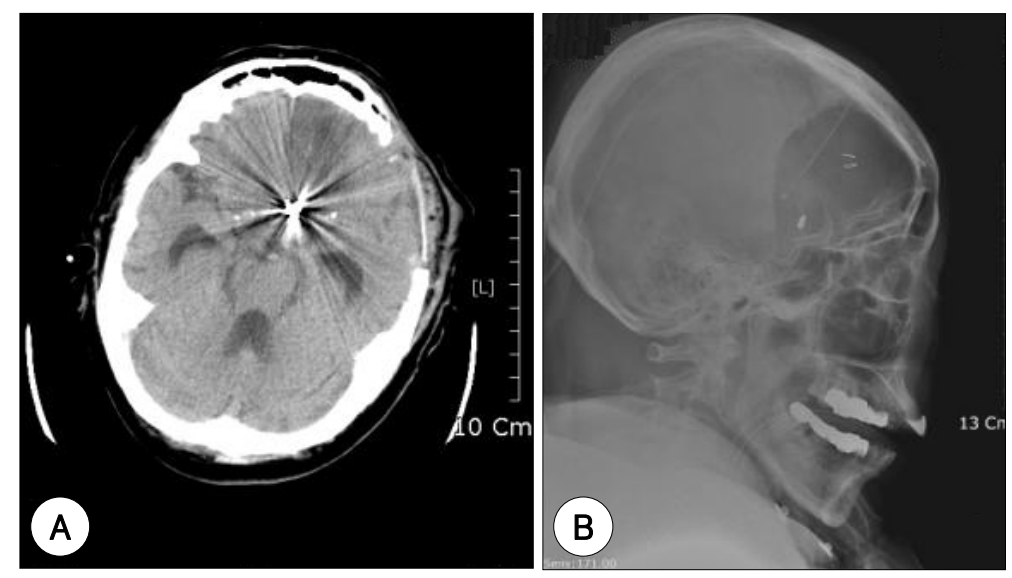

Fig. 6. A : CT shows the infarction in anterior cerebral artery territory with coil artifact. B : Plain skull lateral film shows migrated coil mass at anterior communicating artery junction site.

plications occurred in four patients (4\%) (Fig. 4, 5, 6). Outcomes were good or excellent in 29 patients $(64 \%)$, including the two treated 3 -weeks after initial bleeding. A severe disability or poor outcome was observed in 16 patients $(35.5 \%)$, including two with an $\mathrm{H}-\mathrm{H}$ grade of I or II. Of 5 patients $(11.1 \%)$ who died, $3(60 \%)$ had an $\mathrm{H}-\mathrm{H}$ grade of IV or V. No rebleeding occurred during follow-up. Thirty-two (71\%) patients had Fisher grade III or IV (Table 5). Forty-two (93.3\%) aneurysms were smaller than $15 \mathrm{~mm}$. Satisfactory occlusion rate (total occlusion or neck flow) was achieved in $83 \%$ of patients (Table 3). Aneurysm recanalization was disclosed in two cases. Satisfactory outcome was achieved on : $80.7 \%$ of good grades, $42.1 \%$ of poor grades. Mortality and morbidity rate related to the procedure were $2 \%$ and $6 \%$ respectively.

\section{Discussion}

\section{Background}

The increased incidence of SAH, associated with a similar increase in the prevalence of intracranial aneurysms in elderly populations and with an aging population in the West, makes ruptured aneurysm after the age of 65 years an increasingly frequent pathology in developed countries ${ }^{3446-10) 16) 17) 26)}$. In the literature, chronic arterial hypertension is associated with SAH caused by aneurysm in $28 \%$ to $65 \%$ of cases. Most epidemiological studies agree that there is an increase in the incidence of SAH with advancing age ; however, some authors believe that there is not a continuous increase and they argue that a maximum level is reached by the 
age of 70 years, then a decrease is expected. However, others confirm that there is an increase in the incidence of SAH in a linear model even in patients older than 70 years. As the incidence of SAH increases with the advancing of age and elderly people are an expanding proportion of the population, mainly in developed countries, we shall expect to face more usually ruptured intracranial aneurysms in the elderly ; therefore, we should be aware of the results, before retaining a surgical, endovascular or even a conservative management. Until recently, many authors stated that the best option for ruptured aneurysm in old persons should be conser vative management, since surgical mortality was too high.

Since the appearance of the Guglielmi detachable coils (GDC, Boston Scientific, Boston, USA) in 1990, the technical advances in this field have been tremendous, and the use of endovascular aneurysm treatment is increasing ${ }^{1225) 899) 17(20) 25)}$. It has been suggested that elderly SAH-patients would benefit from endovascular aneurysm treatment, since it is less invasive than craniotomy and should thus inflict less secondary injury to the vulnerable aged brain. The studies with a small number of patients aged 70 years or older have shown favorable results. Good outcome was reported in one study comparing patients 65 years or older with younger patients. Recently, the results of the first large multicenter randomized study The International Subaraclnoid Aneurysm Trial(ISAT) showed significantly better outcome overall after endovascular treatment compared with surgery ${ }^{17}$. They report the 1-year outcomes for 1,063 of 1,073 patients allocated to endovascular treatment, and 1,055 of 1,070 patients allocated to surgical treatment. 250 $(23.5 \%)$ of 1,063 patients allocated to endovascular treatment were dead or dependent at 1 year, compared with $326(30.9 \%)$ of 1055 patients allocated to neurosurgery, an absolute risk reduction of $7.4 \%$ (95\% CI 3.6$11.2, \mathrm{p}=0.0001)$. The early survival advantage was maintained for up to 7 years and was significant (log rank $p=0.03$ ). The risk of epilepsy was substantially lower in patients allocated to endovascular treatment. The results of endovascular aneurysm treatment in elderly patients in particular remain to be evaluated in a large series of patients. It is desirable to evaluate the tolerance and benefit of endovascular aneurysm treatment specifically in elderly SAH patients.

\section{Complications}

The procedure of endovascular coiling of intracranial aneurysm has been described in the literature ${ }^{2) 16)}$. However, specific situations may be encountered in elderly people. Tortuosity or stenosis of the femoral and/or supraaortic vessels may limit intracranial arterial access. Common carotid artery puncture were performed to allow better catheter pushability and stability. Endovascular treatment was performed with heparinization, and the common carotid artery was compressed for 15 minutes at the end of the procedure to prevent any local complication at the puncture site.

Sedat et $\mathrm{al}^{25)}$ showed that thromboembolic events during embolization of a ruptured aneurysm are more frequent in elderly people than in younger patients $(13 \%$ vs $4.2 \%)$. Although our results were not compared with those of younger patients, they seem to confirm these findings. The higher rate of embolic complication is probably related to atheromatous degeneration and tortuosity of the intracranial and/or the supra-aortic vessels that may increase the difficulty of catheterization and the duration of treatment. The high incidence of complications in the oldest patients is probably related, on the one hand, to atheromatous degeneration of the cerebral and cervical arteries and, on the other hand, to the sinuous nature of these arteries, which makes catheterization more difficult and the risk of embolism greater. Endovascular therapy in such circumstances requires greater precaution when catheterizing and a different anticoagulation protocol. It seems to be effective in preventing recurrent aneurysmal bleeding and represents an alternative to surgery in the treatment of ruptured intracranial aneurysms in patients aged 65 years. The clinical results observed at 1 year after embolization are comparable to those obtained in the best surgical series and depend mainly on clinical and CT grades on admission. Endovascular treatment of intracranial aneurysms in patients aged 65 years presents more risks than in a younger population because of a greater frequency of thromboembolic complications. Even thought it is well known that the cervical and intracranial tortuosity of arteries can preclude EVT and that elderly persons are supposed 
to have more tortuous arteries then young subjects, in this series, aneurysms were accessible in all patients This high percentage of complications may be related to the change in cervical and intracranial arteries secondary to ageing, mainly atherosclerosis.

In cases of wide-necked aneurysms, the remodeling technique has proved to be effective, preventing coil protrusion into the parent artery. This technique is associated with a higher rate of embolic complications because of the second microcatheter and successive parent-artery occlusions. In the present series, the remodeling technique was successfully performed in seven patients without any complications ; this result supports the application of this technique, even in elderly people.

\section{Aneurysm location}

The aneurysm location seems to be an important determining factor for clinical outcome. In spite of small numbers, differences in outcome depending on aneurysm location were seen ; however, any interpretation should be made with caution. The highest proportion of favorable outcomes and lowest proportion of severe disabilities were seen in patients with internal carotid artery (ICA) and posterior communicating artery (PComA) aneurysms, whereas the most severe disability was seen in patients with aneurysms on the anterior cerebral artery and anterior communicating artery. Half of the patients with an middle cerebral artery (MCA) aneurysm had a poor outcome and only one enjoyed a favorable outcome, which could imply that the endovascular aneurysm treatment of MCA aneurysms is associated with higher risks. This may be due to the commonly encountered configuration of multiple branches arising adjacent to the aneurysm neck. Careful selection of suitable MCA aneurysms for endovascular treatment is fundamental for good results. Middle cerebral artery aneurysms may be less suitable for endovascular coil embolization in elderly patients ${ }^{9-11) 14) 22 \text {. }}$

\section{Risk \& Benefit}

The main reason for partial occlusion is probably that the goal in this age group was to prevent the ruptured aneurysm from rebleeding without running too great a risk of procedural complications such as unintentional artery occlusion. It is reasonable to believe that a partly occluded aneurysm may be sufficient and satisfactory for the remainder of a patient's expected lifespan, but a small sequela may substantially decrease the quality of life in this age group. For aneurysms with a residual sac flow, either a stable evolution or an intraneurysmal thrombosis resulting in exclusion or partial occlusion with neck flow were seen. The same phenomenon was identified with aneurysms with a residual neck flow. These results are in agreement with Sedat et al. and Birchal et al., who occluded almost completely most of patients $(81 \%$ and $93 \%$ of aneurysms, respectively) as they did for young subjects ${ }^{25)}$. On the other hand Sawada et al. could have complete exclusion or a small neck remnant in just $36 \%$ of treated patients ${ }^{24)}$. However, none of the present series of elderly patients treated by endovascular route rebled, thus we could assume that EVT can effectively protect ruptured aneurysms. Even though the follow-up period was not uniform, we could also consider that it is not always necessary to achieve complete aneurysmal exclusion for patient protection.

Finally, it should be considered that as this specific population is closer to the average life expectancy, securing the ruptured part of the aneurysm by means of partial coiling could be the goal of the treatment in complex cases, because we can avoid rebleeding without treating the permeability of the parent artery planning to achieve full exclusion ${ }^{7) 18) 26}$. We believe that the functional and clinical state of the patients prior to the bleeding should be investigated, and that no variable should be taken alone for precluding treatment for this high risk population ; however, in our study of EVT for ruptured aneurysms in elderly patients, the only baseline feature associated with patient outcome was neurological state on admission. The results presented in this article ensured us to consider elderly patients as primary candidates for EVT, mainly for patients in good neurological state. Nonetheless, one should be aware that the risk of technical complications is most important in this particular group.

\section{Conclusion}

Selective embolization of ruptured intracranial aneu- 
rysms in patients aged 65 years or older is effective and prevents rebleeding. And it represents an alternative to surgery with lower morbidity and mortality rates in select cases. EVT can be considered as a first therapeutic option for elderly persons, since an overall favourable outcome could be achieved in most cases, However, thromboembolic events during embolization of a ruptured aneurysm are more frequent in elderly people than in younger patients. Further studies should be performed to define precisely the predictors of outcome in elderly after SAH in order to give a more exact orientation for decision-making process.

\section{References}

1) Bracard S : Endovascular treatment of Hunt and Hess grade IV and V aneurysms. AJNR Am J Neuroradiol $2002 ; 23: 953-957$

2) Brilstra EH, Rinkel GJ, van der Graaf Y, van Rooij WJ, Algra A : Treatment of intracranial aneurysms by embolization with coils : a systematic review. Stroke 1999 ; $30: 470-476$

3) Chung RY, Carter BS, Norbash A, Budzik R, Putman C, Ogilvy CS : Management outcomes for ruptured and unruptured aneurysms in the elderly. Neurosurgery 2000 ; $47: 827-833$

4) Fridriksson SM, Hillman J, Saveland H, Brandt L : Intracranial aneurysm surgery in the 8th and 9th decades of life : impact on population-based management outcome. Neurosurgery $1995 ; 37: 627-635$

5) Guglielmi G, Vinuela F, Dion J, Duckwiler G : Electrothrombosis of saccular aneurysms via endovascular approach. part 2 : preliminary clinical experience. J Neurosurg $2004 ; 25: 1058-106$

6) Hamada J, Hasegawa S, Kai Y, Morioka M, Fujioka S, Ushio Y : Surgery and long-term outcome for ruptured anterior circulation aneurysms in patients in their ninth decade of life. Surg Neurol $1999 ; 52$ : 123-126 ; discussion 126-127

7) Hutter BO, Kreitschmann-Andermahr I, Gilsbach JM : Health-related quality of life after aneurysmal subarachnoid hemorrhage : impacts of bleeding severity, computerized tomography findings, surgery, vasospasm, and neurological grade. J Neurosurg $2001 ; 94: 241-251$

8) Johansson M, Cesarini KG, Contant CF, Persson L, Enblad P : Changes in intervention and outcome in elderly patients with subarachnoid hemorrhage. Stroke 2001 ; $32: 2845-2949$

9) Johansson M, Norback O, Gal G, Cesarini KG, Tovi M, Solander S, Contant CF, Ronne-Engstrom E, Enblad P : Clinical outcome after endovascular coil embolization in elderly patients with subarachnoid hemorrhage. Neuroradiology $2004 ; 46: 385-391$

10) Inagawa $T:$ Management outcome in the elderly patient following subarachnoid hemorrhage. JNeurosurg 1993 ; $78: 554-561$

11) Inagawa $T:$ What are the actual incidence and mortality rates of subarachnoid hemorrhage? Surg Neurol $1997 ; 47: 47-53$

12) Inagawa $T$, Yamamoto $M$, Kamiya $K$, Monden $S$ : Management of elderly patients with aneurysmal subarachnoid hemorrhage. J Neurosurg $1988 ; 69: 332-339$

13) Iwamoto H, Kiyohara Y, Fujishima M, Kato I, Nakayama K, Sueishi K, Tsuneyoshi M : Prevalence of intracranial aneurysms in a Japanese community based on a consecutive autopsy series during a 30-year observation period : the Hisayama study. Stroke 1999 ; 30 : 1390-1395

14) Lan $Q$, Ikeda $H$, Jimbo $H$, Izumiyama $H$, Matsumoto $\mathrm{K}$ : Considerations on surgical treatment for elderly patients with intracranial aneurysms. Surg Neurol 2000 ; $53: 231-238$

15) Lanzino G : Age and outcome after aneurysmal subarachnoid hemorrhage : why do older patients fare worst? J Neurosurg $1996 ; 85: 410-418$

16) Lubicz B, Leclerc X, Gauvrit JY, Lejeune JP, Pruvo JP : Endovascular treatment of ruptured intracranial aneurysms in elderly people. AJNR Am J Neuroradiol 2004 ; $25: 592-595$

17) Mont'alverne F, Musacchio $M$, Tolentino $V$, Riquelme $C$, Tournade A : Endovascular management for intracranial ruptured aneurysms in elderly patients : outcome and technical aspects. Neuroradiology $2005 ; 47: 446-457$

18) Ogden JA, Mee EW, Henning MA. A : Prospective study of impairment of cognition and memory and recovery after subarachnoid hemorrhage. Neurosurgery 1993 ; $33: 572-587$

19) O'Sullivan MG, Dorward N, Whittle IR, Steers AJ, Miller JD : Management and long-term outcome following subarachnoid haemorrhage and intracranial aneurysm surgery in elderly patients : an audit of 199 consecutive cases. Br J Neurosurg $1994 ; 8: 23-30$

20) Raftopoulos C, Mathurin P, Boscherini D, Billa RF, 
Van Boven M, Hantson P : Prospective analysis of aneurysm treatment in a series of 103 consecutive patients when endovascular embolization is considered the first option. J Neurosurg $2000 ; 93: 175-182$

21) Rosenørn J, Eskesen V, Schmidt K : Age as a prognostic factor after intracranial aneurysm rupture. $\mathrm{Br} J$ Neurosurg $1987 ; 1: 335-341$

22) Sakaki S, Ohta S, Ohue S, Kohno K, Matsuoka K : Outcome in elderly patients with ruptured intracranial aneurysm. Clin Neurol Neurosurg $1989 ; 91: 21-27$

23) Sarti C, Tuomilehto J, Salomaa V, Sivenius J, Kaarsalo E, Narva EV, Salmi K, Torppa J : Epidemiology of subarachnoid hemorrhage in Finland from 1983 to 1985. Stroke $1991 ; 22: 848-853$

24) Sawada M, Kaku Y, Hayashi K, Ueda T, Yoshimura S, Sakai N : Endovascular treatment of ruptured intracranial aneurysms using platinum coils in patients over 70 years of age. Intervent Neuroradiol $2000 ; 6: 85-88$
25) Sedat J, Dib M, Lonjon M, Litrico S, Von Langsdorf D, Fontaine D, Paquis P : Endovascular treatment of ruptured intracranial aneurysms in patients aged 65 years and older : follow-up of 52 patients after 1 year. Stroke 2002 ; $33: 2620-2625$

26) Stachniak J, Layon A, Day A, Gallagher T : Craniotomy for intracranial aneurysm and subarachnoid hemorrhage. Stroke $1996 ; 27: 27-281$

27) Yamashita K, Kashiwagi $S$, Kato $S$, Takasago T, Ito H : Cerebral aneurysms in the elderly in Yamaguchi, Japan : analysis of the Yamaguchi Data Bank of cerebral aneurysm from 1985 to 1995. Stroke $1998 ; 28: 1926-1933$

28) Weir R, Marcellus M, Do H, Steinberg G, Marks M : Aneurysmal subarachnoid hemorrhage in patients with Hunt and Hess grade IV or V : treatment using Guglielmi detachable coil system. AJNR Am J Neuroradiol $2003 ; 24: 585-590$ 